\title{
Het Wetsvoorstel bestuur en toezicht rechtspersonen in relatie tot sectorale regels en governancecodes voor stichtingen
}

\author{
Mr.dr. M.J. van Uchelen-Schipper*
}

\begin{abstract}
$\mathrm{Nu}$ (de herziene versie van) het Wetsvoorstel bestuur en toezicht rechtspersonen weer volop in behandeling is bij de Tweede Kamer komen belangrijke wijzigingen in Boek 2 $B W$ voor stichtingen steeds dichterbij. Voor veel soorten stichtingen gelden aanvullende sectorale wetten en governancecodes. In dit artikel komt aan de orde hoe de aankomende wijzigingen zich verhouden tot dergelijke sectorwetten en codes.
\end{abstract}

\section{Inleiding}

Het in 2016 verschenen Wetsvoorstel bestuur en toezicht rechtspersonen (hierna: Wetsvoorstel BTRP) heeft enige tijd stilgelegen, maar is sinds eind 2018 weer in behandeling bij de Tweede Kamer. ${ }^{1}$ Recentelijk verschenen twee nota's van wijziging en inmiddels is aangekondigd dat de herziene versie van het Wetsvoorstel BTRP (versie 2019) in stemming zal worden gebracht in de Tweede Kamer. Het ziet ernaar uit dat de voorgestelde regels binnen afzienbare tijd in Boek 2 Burgerlijk Wetboek (BW) opgenomen zullen worden.

De essentie van het Wetsvoorstel BTRP is het verbeteren van de kwaliteit van bestuur en toezicht en het stimuleren van professionalisering bij stichtingen en verenigingen (waaronder coöperaties en onderlinge waarborgmaatschappijen), aldus de minister voor Rechtsbescherming. ${ }^{2}$ In dit artikel ga ik slechts in op de wijzigingen voor stichtingen. Gemakshalve ga ik er

Mr. dr. M.J. van Uchelen-Schipper is kandidaat-notaris bij Houthoff en docent aan de Universiteit van Amsterdam.

1. Op 9 november 2018 verschenen de nota naar aanleiding van het verslag, Kamerstukken II 2018/19, 34491, 6, en de nota van wijziging, Kamerstukken II 2018/19, 34491, 7. Bovendien werd op 19 december 2018 het nader verslag, Kamerstukken II 2018/19, 34491, 8, vastgesteld. Op 15 februari 2019 volgde de nota naar aanleiding van het nader verslag, Kamerstukken II 2018/19, 34491, 9, en de tweede nota van wijziging, Kamerstukken II 2018/19, 34491, 10.

2. Kamerstukken II 2018/19, 34491, 9, p. 1. daarbij van uit dat het Wetsvoorstel BTRP in de huidige vorm zal worden aangenomen. ${ }^{3}$

Het huidige algemene stichtingenrecht (titel 6 van Boek 2 BW) bevat een zeer beperkte governanceregeling. Feitelijk komt deze erop neer dat iedere stichting een bestuur dient te hebben dat uit ten minste één lid bestaat. Terzijde wordt in Boek 2 BW de mogelijkheid genoemd om een toezichthoudend orgaan in te stellen. ${ }^{4}$ Voor veel soorten stichtingen gelden sectorale wetten en governancecodes die eveneens ten doel hebben om het bestuur en het interne toezicht verder te professionaliseren. Sectorregels vullen de regels van Boek $2 \mathrm{BW}$ voor de desbetreffende sector aan, mede vanwege het feit dat Boek $2 \mathrm{BW}$ voor stichtingen nauwelijks governanceregels bevat.

\subsection{Wetsvoorstel BTRP}

Het Wetsvoorstel BTRP biedt onder meer een wettelijke basis voor de instelling van een raad van toezicht bij stichtingen. In het Wetsvoorstel BTRP wordt overigens, net als bij andere rechtspersonen, de term raad van commissarissen gebruikt, maar daaraan wordt toegevoegd dat de raad van commissarissen van een stichting ook als raad van toezicht kan worden aangeduid (art. 2:292a lid 1 Wetsvoorstel BTRP). Hierna zal ik uitgaan van de in de praktijk bij veel soorten stichtingen voorkomende term 'raad van toezicht'. ${ }^{5}$ Bovendien regelt het Wetsvoorstel BTRP voor stichtingen het monistisch bestuursmodel: de one-tier board (art. 2:291a Wetsvoorstel BTRP).

3. In mijn proefschrift uit april 2018 deed ik een aantal aanbevelingen ten aanzien van de oorspronkelijke versie van het Wetsvoorstel BTRP. M.J. van Uchelen-Schipper, De rol en positie van de raad van toezicht van de stichting (diss. Utrecht; IVOR nr. 112), Deventer: Wolters Kluwer 2018 (hierna: Van Uchelen-Schipper 2018).

4. Indien er een toezichthoudend orgaan is ingesteld, dienen de leden van dit orgaan de jaarrekening te ondertekenen, aldus art. 2:300 lid 1 BW. Bovendien is dit orgaan bevoegd om de jaarrekening vast te stellen, maar de statuten kunnen anders bepalen (art. 2:300 lid 3 BW).

5. Zie ook Kamerstukken II 2018/19, 34491, 6, p. 4, waar wordt opgemerkt dat veel sectorale governancecodes de term raad van toezicht hanteren. 


\section{Maandblad}

Ondernemingsrecht

Het Wetsvoorstel BTRP verruimt voorts de gronden waarop belanghebbenden via de rechtbank bestuurders kunnen ontslaan en biedt belanghebbenden, anders dan nu, ook de mogelijkheid om leden van de raad van toezicht via de rechtbank te ontslaan (art. 2:298 lid 1 Wetsvoorstel BTRP). ${ }^{6}$

\subsection{Sectorregels voor stichtingen}

In Nederland komen veel verschillende soorten stichtingen voor, zoals culturele instellingen, goede doelen, pensioenfondsen, claimstichtingen, zorginstellingen, woningcorporaties en scholen. Voor veel van deze stichtingen gelden, al dan niet op basis van vrijwilligheid, sectorale governancecodes. Governancecodes zijn een vorm van zelfregulering met principes en aanbevelingen en worden doorgaans opgesteld door brancheorganisaties. ${ }^{7} \mathrm{Zij}$ kunnen inspelen op actualiteiten en ontwikkelingen in de desbetreffende sector en worden, mede om die reden, met enige regelmaat herzien en aangepast. Sinds 1 januari 2017 is er bijvoorbeeld een vernieuwde Governancecode Zorg. Van nog recentere datum is de herziene Governance Code Cultuur: deze is op 1 januari 2019 van kracht geworden. Bovendien is er een herziening van de Governancecode Woningcorporaties in de maak. ${ }^{8}$

Niet alleen sectorale governancecodes, maar ook sectorwetten en daarop gebaseerde uitvoeringsregelingen, zoals voor zorginstellingen de Wet toelating zorginstellingen (WTZi) en de Uitvoeringsregeling WTZi en voor woningcorporaties de Woningwet en het Besluit toegelaten instellingen volkshuisvesting, bevatten regels voor het bestuur en het toezichthoudend orgaan van stichtingen in die sector. Daarnaast bevatten zij regels die belanghebbenden(organen), zoals de cliëntenraad bij een zorginstelling, een bepaalde mate van invloed geven op het bestuur en het toezichthoudend orgaan.

\subsection{Vraagstelling en opbouw van dit artikel}

Het Wetsvoorstel BTRP bevat mijns inziens een aantal belangrijke verduidelijkingen ten opzichte van de huidige regeling van de stichting in Boek $2 \mathrm{BW}$. Het biedt bovendien een basis om de interne governance voor bepaalde soorten stichtingen per sector verder uit te werken. Daarbij komt de vraag op wat de voorgestelde wijzigingen in Boek 2 BW betekenen voor sectorwetten en sectorcodes. Is er sprake van overlap of strijdigheid met deze regels en welke aanvullingen op het Wetsvoorstel BTRP zijn wenselijk of noodzakelijk? Ik heb mij afgevraagd welke onderwerpen in verband met de nadere invoering van het Wetsvoorstel BTRP extra aandacht verdienen van de opstellers van sectorregels en governancecodes. In het bestek van dit artikel kunnen niet alle sectorale regelingen

6. Zie over het gewijzigde voorstel ook G.J.C. Rensen, Wetsvoorstel bestuur en toezicht rechtspersonen in de rebound, WPNR 2019/7223. Ten opzichte van de oorspronkelijke versie uit 2016 springt in het oog dat niet langer is voorgesteld om de regels van bestuur en toezicht te uniformeren in titel 1 van Boek 2 BW.

7. Zie Van Uchelen-Schipper 2018, p. 54-67 en 508.

8. De genoemde codes zijn te vinden via www.governancecodezorg.nl, www.cultuur-ondernemen.nl en www.aedes.nl. Zie voor een lijst met governancecodes ook Van Uchelen-Schipper 2018, p. XVIII en 525. en codes voor stichtingen worden genoemd. Hier en daar zullen bepalingen uit sectorwetten en sectorcodes worden uitgelicht en zullen (specifiek of meer in het algemeen) suggesties voor dergelijke regels worden gedaan.

In dit artikel behandel ik allereerst de soorten governancemodellen die bij stichtingen in verschillende sectoren voorkomen. Daarbij komt de vraag aan de orde of deze modellen aansluiten bij het Wetsvoorstel BTRP. Vervolgens beschrijf ik de kerntaken en kernbevoegdheden van het bestuur en de raad van toezicht die in het Wetsvoorstel BTRP zijn opgenomen en ga ik na welke punten uitgewerkt kunnen worden in sectorregels. Tot slot ga ik in op de mogelijkheden die het nieuwe artikel 2:298 BW biedt aan belanghebbenden om bestuurders en leden van de raad van toezicht via de rechter te schorsen en te ontslaan. In sommige sectoren is aan belanghebbenden(organen) de bevoegdheid toegekend om een enquêteprocedure in te stellen. Aan de orde komt hoe de mogelijkheden van artikel 2:298 BW zich verhouden tot de mogelijkheid om via de Ondernemingskamer in een enquêteprocedure (bij wijze van voorziening) bestuurders en leden van de raad van toezicht te schorsen of te ontslaan.

\section{Governancemodellen}

\subsection{Raad-van-toezichtmodel}

Zoals opgemerkt biedt het Wetsvoorstel BTRP een wettelijke basis voor de instelling van een raad van toezicht. 'Grote stichtingen' in veel sectoren kennen een governancemodel met een bestuur en een afzonderlijke raad van toezicht (raad-van-toezichtmodel). ${ }^{9}$ In sommige sectoren kiezen grote stichtingen vaak vrijwillig voor het instellen van een raad van toezicht, zoals bijvoorbeeld grotere musea in de culturele sector. Voor sommige soorten stichtingen, zoals zorginstellingen en woningcorporaties (die ik hierna voor het gemak 'woningstichtingen' noem), wordt een raad van toezicht verplicht voorgeschreven in sectorregels. Zoals reeds door velen is opgemerkt, valt niet goed in te zien waarom een model met uitvoerende en niet-uitvoerende bestuurders (monistisch bestuursmodel, ook wel one-tier board genoemd) voor stichtingen in deze sectoren niet toegestaan is. ${ }^{10}$ In de pensioensector en de onderwijssector mogen stichtingen immers wel een one-tier board instellen.

9. Het begrip 'grote stichting' is niet vastomlijnd. In bepaalde wetsartikelen, zoals art. 2:297a en 2:297b BW (maximumaantal bestuurlijke en toezichthoudende functies bij grote stichtingen), wordt in dat verband verwezen naar de regels van het jaarrekeningenrecht. Het begrip 'grote stichting' kan echter ook ruimer worden gezien, te weten: een stichting die een onderneming van een bepaalde omvang heeft en/of een (uit publiek geld gevormd) vermogen van een bepaalde omvang en/of inkomsten uit giften die een bepaald bedrag te boven gaan. Van Uchelen-Schipper 2018, p. 7.

10. Zie o.m. C.H.C. Overes, Bestuurlijke inrichting van semipublieke instellingen, in: Eenheid en verscheidenheid in het ondernemingsrecht (IVOR nr. 98), Deventer: Wolters Kluwer 2016 en M.J. van UchelenSchipper, Toezicht op het bestuur, TvOB 2016, afl. 1, p. 3-12. 


\subsection{One-tier board}

Algemeen wordt aangenomen dat het nu al mogelijk is dat een stichting op grond van de statuten een bestuur instelt met verschillende soorten bestuurders, dat wil zeggen: uitvoerende en niet-uitvoerende bestuurders, maar bijvoorbeeld ook algemene en dagelijkse bestuurders (zie ook par. 2.3). Dit is vooralsnog niet in Boek 2 BW vastgelegd, maar het Wetsvoorstel BTRP brengt daarin verandering. Ook voor stichtingen komt er een wettelijke basis voor de one-tier board, waarbij net als bij BV's en NV's de term uitvoerende en niet-uitvoerende bestuurders wordt gehanteerd (art. 2:291a Wetsvoorstel BTRP). ${ }^{11}$ De uitdrukkelijke wettelijke regeling in Boek 2 BW geeft wellicht een boost aan verschillende sectoren om de one-tier board toe te staan als alternatief voor het raad-van-toezichtmodel en deze mogelijkheid, anders dan nu, ook uitdrukkelijk te noemen en te reguleren in sectorwetten en sectorcodes.

Het Wetsvoorstel BTRP laat in het midden wie bij een stichting de bestuurders benoemt. In geval van een one-tier board kunnen de stichtingsstatuten bepalen dat het bestuur zijn eigen leden benoemt (coöptatie). Sectorwetten en governancecodes zouden mijns inziens aan de algemene wettelijke regeling dienen toe te voegen dat, in geval van coöptatie, slechts de niet-uitvoerende bestuurders besluiten nemen omtrent benoeming en ontslag van niet-uitvoerende bestuurders. ${ }^{12}$ Het is immers niet wenselijk dat de uitvoerende bestuurders betrokken worden bij de benoeming en het ontslag van hun eigen interne toezichthouders. ${ }^{13}$ Verder is aan te bevelen dat in sectorregels wordt voorgeschreven dat de niet-uitvoerende bestuurders binnen het bestuur in de meerderheid zijn. ${ }^{14}$ Belanghebbendenorganen, zoals de cliëntenraad bij een zorginstelling of de huurdersraad bij een woningstichting, die nu het recht hebben om leden van de raad van toezicht voor te dragen, zouden in geval van een one-tier board het recht dienen te krijgen om niet-uitvoerende bestuurders voor te dragen.

\section{$2.3 \mathrm{AB} / \mathrm{DB}$-model en bestuur/directiemodel}

In de praktijk komen bij stichtingen verschillende varianten van het model met een algemeen bestuur $(\mathrm{AB})$ en een dagelijks

11. En overigens ook voor verenigingen, coöperaties en onderlinge waarborgmaatschappijen.

12. Een dergelijk besluit geldt dan als een besluit van het gehele bestuur. Zie ook art. 2:291a lid 2 Wetsvoorstel BTRP.

13. Art. 2:291a lid 1 Wetsvoorstel BTRP bepaalt slechts dat het doen van voordrachten voor de benoeming van een bestuurder niet aan een uitvoerende bestuurder kan worden toebedeeld.

14. Zie ook Bpb 5.1.1 NCGC. Deze meerderheid is bijv. van belang in verband met de bevoegdheid van het bestuur om uitvoerende bestuurders te schorsen. Zie par. 3.2 hierna. Ook zou kunnen worden bepaald dat de taak om uitvoerende bestuurders te schorsen slechts kan worden toebedeeld aan de niet-uitvoerende bestuurders. bestuur (DB) voor. ${ }^{15}$ Indien sprake is van twee afzonderlijke organen, waarbij het $A B$ toezicht houdt op het beleid van het $\mathrm{DB}$, zal de term raad van toezicht of raad van commissarissen passender zijn. Een model waarin het $\mathrm{AB}$ uit zijn midden het DB aanwijst, zal feitelijk een monistisch bestuursmodel zijn. Wellicht zal in dat laatste geval in de toekomst vaker worden aangesloten bij de wettelijke terminologie 'niet-uitvoerende' en 'uitvoerende' bestuurders.

In de praktijk komt ook het model voor waarin slechts het $A B$ het bestuur in de zin van de wet is, maar bestuurlijke taken toekent ('delegeert') aan het DB. ${ }^{16}$ Deze dagelijkse bestuurders worden benoemd en ontslagen door en zijn ondergeschikt aan het statutair bestuur en vormen een titulair bestuur. Het titulair bestuur wordt in een dergelijk model ook vaak 'directie' genoemd. Bijvoorbeeld bij kleinere culturele instellingen komt het regelmatig voor dat sprake is van een (onbezoldigd) statutair bestuur en een (titulair) directeur, die vaak tevens werknemer van de stichting is.

\subsection{Raad-van-toezichtmodel als uitgangspunt van sectorale governancecodes?}

De inmiddels al wat verouderde codes voor primair onderwijs en voortgezet onderwijs verwijzen, enigszins verwarrend, naar verschillende soorten governancemodellen met verschillende soorten bestuurders, waaronder ook (titulaire) directeuren worden begrepen. ${ }^{17}$ In andere sectoren wordt vaak, als gezegd, het raad-van-toezichtmodel als uitgangspunt gekozen in de desbetreffende code. Wellicht komt dat omdat de Nederlandse Corporate Governance Code (NCGC), die is geschreven voor (Nederlandse) beursvennootschappen, het model met een bestuur en een afzonderlijke raad van commissarissen als uitgangspunt neemt. De huidige NCGC differentieert daarbij echter: in geval van een one-tier board zijn de bepalingen voor de raad van commissarissen van overeenkomstige toepassing op de niet-uitvoerende bestuurders (zie het laatste

15. Zie ook de nota naar aanleiding van het verslag, Kamerstukken II 2018/19, 34491, 6, p. 17 en Van Uchelen-Schipper 2018, p. 194-195. Door veel schrijvers wordt, mijns inziens terecht, aangenomen dat slechts één orgaan bestuur in de zin van de wet kan zijn. Zie hierover ook B. Bier, Wetsvoorstel bestuur en toezicht rechtspersonen: enkele gedachten bij horizontaal, verticaal en diagonaal toezicht, Ondernemingsrecht 2017/105 en M.J. van Uchelen-Schipper, Governance en toezicht, in: J.J.A. Hamers, C.A. Schwarz \& D.F.M.M. Zaman (red.), Handboek stichting en vereniging, Zutphen: Uitgeverij Paris 2018, p. 278.

16. Aldus ook Bier 2017 en Van Uchelen-Schipper 2018. Dit model komt bijv. voor in de onderwijssector. Zie o.m. art. 5 lid 2 sub c van de Code Goed Bestuur in het primair onderwijs, waarover J.M.A. Wintgens-van Luijn, De stichting in het onderwijs, WPNR 2015/7088.

17. Code Goed Bestuur in het primair onderwijs 2014 en Code Goed Onderwijsbestuur VO 2015. De definities 'besturen' en 'bestuurders' in de Code Goed Onderwijsbestuur VO 2015 zijn verwarrend en sluiten niet aan op Boek 2 BW. 'Bestuurders' zijn volgens deze code 'personen die de bestuurlijke functie uitoefenen' en 'besturen' zijn gedefinieerd als 'de organen of personen in het VO die de bestuurlijke functie binnen een onderwijsorganisatie uitoefenen. Dit kunnen zijn een college van bestuur, een directeur-bestuurder, een (dagelijks) bestuur, of het collectief van personen die binnen een zogenoemd one-tier bestuur de bestuurlijk functie uitoefenen.' 


\section{Maandblad \\ Ondernemingsrecht}

hoofdstuk van de NCGC). Als de one-tier board in verschillende sectoren voor stichtingen wordt toegestaan als alternatief voor het raad-van-toezichtmodel, zou deze ook genoemd en uitgewerkt moeten worden in de desbetreffende sectorale governancecodes. Daarbij zou voor dezelfde handelwijze als in de NCGC kunnen worden gekozen en een apart hoofdstuk voor de one-tier board kunnen worden geschreven.

In de culturele sector is naar aanleiding van de laatste versie van de Governance Code Cultuur kritiek geuit op het feit dat het raad-van-toezichtmodel het uitgangspunt is van de code, aangezien er veel kleine instellingen zijn die het bestuur/directiemodel hanteren. De vraag kan worden gesteld of ook dit bestuur/directiemodel geregeld zou moeten worden in de desbetreffende governancecode. Een moeilijkheid is echter dat er niet één vast bestuur/directiemodel bestaat. ${ }^{18}$ Een belangrijker argument om het bestuur/directiemodel niet in een governancecode te regelen, is mijns inziens dat het (statutaire) bestuur, dat één of meer (titulaire) directeuren aanstelt, eindverantwoordelijk is voor de directeuren, dat wil zeggen: het bestuur legt over hun handelen verantwoording af naar derden en kan daarop worden aangesproken.

Ik meen dat governancecodes zich primair zouden dienen te richten tot de wettelijke (Boek $2 \mathrm{BW}$ ) organen: het bestuur en de raad van toezicht. Daarbij merk ik wel op dat sommige governancebepalingen niet alleen op het bestuur van toepassing zouden moeten zijn, maar dat het bestuur deze ook zou moeten 'doorgeven' aan de directie en aan (andere) werknemers van de stichting. Te denken valt vooral aan good governance-bepalingen uit codes die zien op individueel gedrag en handelen, zoals bepalingen op het gebied van integriteit. Maar ook bepalingen en beleid op het gebied van diversiteit zijn relevant voor de directie en eventueel voor (andere) werknemers. ${ }^{19}$ Sectororganisaties kunnen daarbij behulpzaam zijn en kunnen in handreikingen voorbeelden aanleveren van 'governancebepalingen' die in een directiereglement kunnen worden opgenomen.

\section{Wettelijke basisregeling en kernbevoegdheden van bestuur en raad van toezicht}

Als het Wetsvoorstel BTRP wet wordt, zal Boek 2 BW de kerntaak, normstelling en kernbevoegdheden voor het bestuur en de raad van toezicht van een stichting bevatten. Een belangrijke wettelijke bevoegdheid van de raad van toezicht is de bevoegdheid om de bestuurders te schorsen. Daarnaast krijg

18. De huidige versie van de NCGC bevat een bepaling over het model met een executive committee (hierna: ExCo). Onder ExCo wordt verstaan: een commissie die nauw betrokken is bij de besluitvorming van het bestuur en waarvan naast leden van het bestuur ook leden van het senior management deel uitmaken (NCGC Toelichting op Bpb 2.1.3, p. 45). De bepalingen in de NCGC over de ExCo hebben in de literatuur tot vragen geleid. Een belangrijke reden voor onduidelijkheid is dat er simpelweg niet één model met een ExCo bestaat. Zie hierover bijv. Ch.E. Honée, Governance aspecten van het Executive Committee, en de vraag: waar staan zijn leden?, Ondernemingsrecht 2018/21.

19. Op grond van Bpb 2.1.5 NCGC strekt het diversiteitsbeleid bij een beursvennootschap zich uit tot de ExCo. de raad van toezicht een wettelijke rol bij tegenstrijdig belang van alle bestuurders van de stichting. Het Wetsvoorstel BTRP bepaalt dat de statuten aanvullende bepalingen omtrent de taak en bevoegdheden van de raad van toezicht kunnen bevatten (art. 2:292a Wetsvoorstel BTRP). Uiteraard kunnen ook sectorregels en governancecodes de taken en bevoegdheden van het bestuur en de raad van toezicht uitwerken en aanvullen.

\subsection{Algemene taak en normstelling}

Het huidige artikel 2:291 BW bepaalt slechts dat het bestuur is belast met het besturen van de stichting. Net als voor de raad van commissarissen van andere rechtspersonen wordt voor de raad van toezicht van stichtingen vastgelegd dat deze tot taak heeft om toezicht te houden op het beleid van het bestuur en de algemene gang van zaken (art. 2:292a lid 2 Wetsvoorstel BTRP). In de wet wordt straks ook uitdrukkelijk geregeld dat zowel bestuurders als leden van de raad van toezicht zich bij de vervulling van hun taak moeten richten naar het belang van de stichting en de met haar verbonden onderneming of organisatie (art. 2:291 lid 3 en 2:292a lid 2 Wetsvoorstel BTRP). Algemene taken en normstellingen in sectorcodes en sectorwetten kunnen worden geschrapt. Het is overbodig en verwarrend dat sommige sectorale regels, zoals de Woningwet, bepalen dat bestuurders en leden van de raad van toezicht zich mede moeten richten op het maatschappelijke belang, aangezien dit op grond van de algemene norm reeds een van de belangen is waarmee bestuurders en toezichthouders rekening moeten houden. ${ }^{20}$ Overigens mag de raad van toezicht van een stichting, net als de raad van commissarissen van andere rechtspersonen, slechts uit natuurlijke personen bestaan (art. 2:292a lid 1 Wetsvoorstel BTRP). Dit lijkt mij eveneens een bepaling die niet herhaald hoeft te worden in sectorregels. $^{21}$

\subsection{Schorsingsbevoegdheid en andere kernbevoegdheden van de raad van toezicht}

Het Wetsvoorstel BTRP biedt, mijns inziens terecht, aan leden van de raad van toezicht de bevoegdheid om te allen tijde tot schorsing van een bestuurder over te gaan (art. 2:292a lid 3 Wetsvoorstel BTRP). Als is gekozen voor een one-tier board heeft het bestuur de bevoegdheid om uitvoerende bestuurders te schorsen (art. 2:291a lid 4 Wetsvoorstel BTRP). Als de niet-uitvoerende bestuurders in de meerderheid zijn en/of deze taak is toebedeeld aan de niet-uitvoerende bestuurders, kunnen zij hiermee ingrijpen in het geval een uitvoerende bestuurder het belang van de stichting schaadt.

Ik merk op dat een merkwaardig verschil is opgenomen in het Wetsvoorstel BTRP tussen de schorsingsbevoegdheid van

20. Zie art. 31 lid 1 derde zin Woningwet. In het Wetsvoorstel BTRP is echter slechts voorgesteld om de eerste twee zinnen van art. 31 Woningwet, waarin de algemene taak van de raad van toezicht is omschreven, te schrappen. Zie hierover Overes 2016, 2018; Van Uchelen-Schipper 2018, p. 292 en 372.

21. Zie bijv. art. 30 lid 1 Woningwet. Zie ook Van Uchelen-Schipper 2018, p. 197-199. 
leden van de raad van toezicht en van de one-tier board. Aan de voorgestelde wettelijke bepaling voor de raad van toezicht is toegevoegd 'tenzij de statuten anders bepalen'. Dat betekent dat de schorsingsbevoegdheid van de raad van toezicht, anders dan de schorsingsbevoegdheid van de one-tier board, in de statuten kan worden weggeschreven. Ik meen dat de schorsingsbevoegdheid van zowel de raad van toezicht als de niet-uitvoerende bestuurders van een stichting een dwingendrechtelijk karakter zou moeten hebben. ${ }^{22}$ Anders dan bij andere rechtspersonen is er immers geen algemene vergadering met een wettelijke schorsingsbevoegdheid. In sectorregels zou om die reden kunnen worden bepaald dat het wegschrijven van deze bevoegdheid niet mogelijk is.

Naast deze schorsingsbevoegdheid zijn weinig bevoegdheden voor de raad van toezicht opgenomen in het Wetsvoorstel BTRP. Zo wordt niet voorgeschreven dat de raad van toezicht van een stichting een voorstel tot juridische fusie moet goedkeuren, terwijl de raad van commissarissen van andere rechtspersonen wel goedkeuring aan het fusievoorstel moet verlenen (art. 2:312 lid $4 \mathrm{BW}) .^{23}$ Van belang is dat extra bevoegdheden van de raad van toezicht (of de niet-uitvoerende bestuurders), waarmee zij hun toezichthoudende taak nader invulling kunnen geven, per sector worden uitgewerkt. Zo zouden sectorwetten en sectorcodes dienen te bepalen dat voorafgaande goedkeuring van de raad van toezicht vereist is voor nader te noemen bestuursbesluiten die materieel zijn voor de stichting.

\subsection{Belet en ontstentenis}

Anders dan in de oorspronkelijke versie van het Wetsvoorstel BTRP is in de huidige versie (versie 2019) niet langer bepaald dat de statuten een regeling dienen te bevatten voor het geval sprake is van belet of ontstentenis van (alle) bestuurders en leden van de raad van toezicht. ${ }^{24}$ Het is onduidelijk waarom deze bepaling niet langer is opgenomen. ${ }^{25}$ Indien sprake is van belet of ontstentenis van alle stichtingsbestuurders en de statuten een coöptatieregeling bevatten, kunnen nieuwe bestuurders slechts via de rechter benoemd worden. Bij belet of ontstentenis van de gehele raad van toezicht heeft de rechter niet de mogelijkheid om nieuwe leden te benoemen. ${ }^{26}$ Zolang Boek 2 BW hier niet in voorziet, zouden sectorwetten en sectorcodes mijns inziens moeten voorschrijven dat een statutaire regeling wordt getroffen voor belet of ontstentenis bij zowel het bestuur als de raad van toezicht. ${ }^{27}$

\subsection{Tegenstrijdig belang en zorgvuldige besluitvorming} Tegenstrijdig belang van bestuurders en leden van de raad van toezicht van een stichting wordt straks in Boek 2 BW geregeld

22. Van Uchelen-Schipper 2018, p. 243.

23. Zie ook Van Uchelen-Schipper 2018, p. 178.

24. In de oorspronkelijke versie van het Wetsvoorstel BTRP was een uniforme bepaling voor alle rechtspersonen opgenomen: art. 9 lid 6 en 11 lid 7 van het oorspronkelijke Wetsvoorstel BTRP.

25. Zie hierover ook Rensen 2019.

26. Zie ook Van Uchelen-Schipper 2018, p. 501-502.

27. Voor woningstichtingen is dit reeds in sectorwetgeving vastgelegd, te weten in art. 25 lid 7 en 30 lid 11 Woningwet. (art. 2:291 lid 4 en 2:292a lid 5 Wetsvoorstel BTRP). Het voorkomen van belangenverstrengeling en omgang met tegenstrijdige belangen is terecht een belangrijk thema in veel sectorale governancecodes. Dergelijke bepalingen over tegenstrijdig belang dienen wel aan te sluiten bij de wettelijke basisregeling.

De voorgestelde wettelijke regeling houdt in dat een bestuurder met een tegenstrijdig belang zich onthoudt van deelname aan de beraadslaging en besluitvorming. In de literatuur is opgemerkt dat het voor de werking van deze regeling van belang is dat een bestuurder zijn tegenstrijdig belang tijdig meldt bij zijn medebestuurders en/of (de voorzitter van) de raad van toezicht, indien deze is ingesteld. ${ }^{28} \mathrm{Nu}$ het Wetsvoorstel BTRP hierover geen bepaling bevat, zou dit mijns inziens in een sectorcode geadresseerd dienen te worden. ${ }^{29}$ Het voorgestelde wetsartikel vervolgt dat, als er ten gevolge van een tegenstrijdig belang geen besluit door het bestuur kan worden genomen, het besluit wordt genomen door de raad van toezicht, indien deze is ingesteld. ${ }^{30} \mathrm{Ik}$ meen dat de raad van toezicht altijd betrokken moet worden als sprake is van tegenstrijdig belang van één of meer bestuurders bij een transactie die materieel is voor de stichting. De raad van toezicht zou in dergelijke gevallen voorafgaande goedkeuring dienen te verlenen. Naar mijn mening betreft dit een kernbevoegdheid die de toezichthoudende taak nader inkleurt (zie par. 3.2). Dit is in de meeste, maar nog niet alle sectorale governancecodes geregeld. ${ }^{31}$

Indien alle bestuurders een tegenstrijdig belang hebben en een raad van toezicht ontbreekt, kan het bestuur het besluit toch nemen, maar dienen de overwegingen die aan het besluit ten grondslag liggen schriftelijk vastgelegd te worden, tenzij de statuten anders bepalen, aldus het Wetsvoorstel BTRP. Ook als alle leden van de raad van toezicht een tegenstrijdig belang hebben, kunnen zij een besluit nemen, mits zij daarbij hun overwegingen schriftelijk vastleggen. Hiermee geven bestuurders en interne toezichthouders inzicht in de redenen om, ondanks het tegenstrijdig belang, de transactie toch door te zetten. Daarbij dienen zij aan te geven waarom zij het

28. Door sommigen, zoals Wezeman (J.B. Wezeman, Vorm en sanctionering van tegenstrijdig belangregels, in: L. Timmerman e.a., Eenheid en verscheidenheid in het ondernemingsrecht (IVOR nr. 98), Deventer: Wolters Kluwer 2016, p. 89-90), en Quist \& Rensen (P.H.N. Quist \& G.J.C. Rensen, De algemene bepalingen in het wetsvoorstel Bestuur en toezicht rechtspersonen, WPNR 2017/7162) was bepleit om dit in het Wetsvoorstel BTRP op te nemen, zodat dit in Boek 2 BW geregeld wordt.

29. Overigens is het ook van belang te regelen aan wie leden van de raad van toezicht hun tegenstrijdig belang melden (slechts aan de voorzitter of aan de hele raad van toezicht). Zie Van Uchelen-Schipper 2018, p. 416.

30. Zie mijn kritiek over escalatie naar de raad van toezicht, aangezien deze ertoe kan leiden dat de raad van toezicht verantwoordelijk wordt gehouden voor een besluit dat verder gaat dan het toezichthoudende terrein. Van Uchelen-Schipper 2018, p. 249-250.

31. Van Uchelen-Schipper 2018, p. 281. Net als in de NCGC zou kunnen worden vastgelegd welke voorgenomen handelingen van het bestuur in ieder geval een ongeoorloofde belangenverstrengeling en mogelijk een tegenstrijdig belang opleveren, zoals het aangaan van een transactie met een familielid of met een rechtspersoon die bestuurd wordt door een familielid. 


\section{Maandblad}

Ondernemingsrecht

besluit in het belang van de stichting achten. Brancheorganisaties zouden handreikingen kunnen opstellen over de wijze waarop tegenstrijdig-belangbesluiten gemotiveerd en toegelicht moeten worden. Schriftelijke vastlegging zal doorgaans plaatsvinden in interne notulen, maar het is ook van belang om belangrijke transacties waarbij tegenstrijdig belang speelde te melden in het jaarlijkse bestuursverslag. ${ }^{32}$ Dergelijke meldingen in bestuursverslagen komen, in ieder geval in de culturele sector, tot nu toe nauwelijks voor. ${ }^{33}$

Overigens meen ik dat sectorale governancecodes en/of handreikingen ook op andere punten zouden kunnen inspringen en bijdragen aan zorgvuldige besluitvorming van zowel het bestuur als de raad van toezicht. Een zorgvuldig en gestructureerd besluitvormingsproces draagt bij aan de kwaliteit van besluiten. Dat geldt met name voor besluiten van de interne toezichthouders, die doorgaans meer tijd hebben om hun beslissingen te nemen dan bestuurders die dagelijks op ad-hocbasis beslissingen moeten nemen. Dit onderwerp is mijns inziens vaak onderbelicht. ${ }^{34}$

\section{Toezicht door belanghebbenden op grond van artikel 2:298 BW en het enquêterecht}

Het sluitstuk van een goede governanceregeling vormt het externe toezicht. Bepaalde soorten stichtingen, zoals pensioenfondsen en semipublieke instellingen (zorginstellingen, woningstichtingen en scholen die door de overheid bekostigd worden), kennen een externe toezichthouder met eigen handhavingsbevoegdheden. ${ }^{35}$ In zekere zin wordt op alle stichtingen extern toezicht gehouden door het Openbaar Ministerie. Het Openbaar Ministerie kan om inlichtingen verzoeken (art. 2:297 BW) en kan via de rechter een stichtingsbestuurder ontslaan (art. 2:298 BW). Ook belanghebbenden hebben deze laatstgenoemde mogelijkheid om de rechter te verzoeken een bestuurder te ontslaan vanwege handelen in strijd met de wet of de statuten of in geval van 'wanbeheer'.

\subsection{Uitbreiding mogelijkheden voor belanghebbenden in Wetsvoorstel BTRP}

In het Wetsvoorstel BTRP worden belangrijke wijzigingen van artikel 2:298 BW voorgesteld. Ten eerste worden de ont-

32. Van Uchelen-Schipper 2018, p. 418.

33. Aldus bijv. het KPMG-rapport 'Reflectie op toezicht, onderzoek naar verantwoording over toezicht in jaarverslagen in de cultuursector', maart 2016.

34. Dit geldt overigens niet alleen voor stichtingen, maar ook voor (beurs)vennootschappen. In het Verenigd Koninkrijk geldt voor beursvennootschappen, in aanvulling op de UK Governance Code, een handreiking: de 'Guidance on Board Effectiveness' van de Financial Reporting Council (FRC), www.frc.org.uk. Daarin is te lezen: 'Many of the factors which lead to poor decision making are predictable and preventable. Boards can minimise the risk of poor decisions by investing time in the design of the decision-making policies and processes including the contribution of committees.' Zie ook Van Uchelen-Schipper 2018, p. 374 en 422-428.

35. Zie uitgebreider hierover Van Uchelen-Schipper 2018, par 6.4. slaggronden van artikel 2:298 BW verruimd. ${ }^{36}$ Daarnaast wordt voorgesteld om artikel 2:298 BW uit te breiden: het Openbaar Ministerie en belanghebbenden kunnen bij de rechtbank ook een verzoek indienen om leden van de raad van toezicht van de stichting te ontslaan (zie lid 5 van het voorgestelde art. 2:298 BW). De minister meent dat de huidige gronden niet toereikend zijn om het ontslag te bewerkstelligen van een bestuurder die het belang van de stichting zodanig schaadt dat het niet langer verantwoord is om hem als bestuurder te handhaven. ${ }^{37}$ Een belanghebbende kan straks de rechter verzoeken om ontslag van een bestuurder of een lid van de raad van toezicht als hij meent dat sprake is van (a) verwaarlozing van de bestuurlijke c.q. toezichthoudende taak, (b) andere gewichtige redenen, of (c) ingrijpende wijziging van de omstandigheden op grond waarvan het voortduren van het bestuurderschap c.q. lidmaatschap van de raad van toezicht in redelijkheid niet kan worden geduld.

\subsection{Wie zijn belanghebbenden in de zin van artikel 2:298 BW?}

Een belangrijke vraag in verband met het huidige én het toekomstige artikel 2:298 BW is wie als belanghebbenden kwalificeren. De discussie over het begrip belanghebbende is nog niet volledig uitgekristalliseerd en het Wetsvoorstel BTRP beoogt geen verandering te brengen in de reikwijdte van het begrip belanghebbende. ${ }^{38}$ Uit de rechtspraak en de memorie van toelichting bij het Wetsvoorstel BTRP volgt dat als belanghebbenden kunnen worden aangemerkt: de stichting zelf, personen die deel uitmaken of hebben uitgemaakt van een stichtingsorgaan, uitkeringsgerechtigden, subsidiegevers (waaronder overheidsinstanties), de Staat (bij semipublieke instellingen op grond van zijn 'stelselverantwoordelijkheid') en de curator (in geval van faillissement). ${ }^{39}$ Een recent arrest van de Hoge Raad zet mogelijk de deur nog iets verder open, zodat ook anderen die nauw betrokken zijn (geweest) bij het onderwerp dat in de procedure wordt behandeld gebruik kun-

36. De huidige grond 'wanbeheer' wordt in de rechtspraak van oudsher geïnterpreteerd als financieel wanbeheer en niet als bestuurlijk wanbeleid in het algemeen. Onder wanbeheer wordt verstaan: een tekortkoming ten aanzien van het beheer van het vermogen of de zorg voor de verkrijging van de inkomsten waarover de stichting kan beschikken; HR 3 januari 1975, NJ 1975/222 (Stichting Vorming Werkende Jeugdigen).

37. Kamerstukken II 2015/16, 34491, 3, p. 7-8.

38. MvT BTRP, p. 35. Uit vaste rechtspraak volgt dat in verband met dit begrip de zogenoemde tweekringenleer kan worden gevolgd, waarbij (1) de eerste kring wordt gevormd door degenen die door de uitkomst van de procedure zodanig in een eigen belang worden getroffen dat zij daarin behoren te mogen opkomen ter bescherming van dat belang, en (2) de tweede kring wordt gevormd door degenen die anderszins zo nauw betrokken zijn (geweest) bij het onderwerp dat in de procedure wordt behandeld, dat daarin een belang is gelegen om in de procedure te verschijnen. HR 10 november 2006, NJ 2007/45 m.nt. J.M.M. Maeijer. Met name over deze tweede kring bestaat onduidelijkheid.

39. Van Uchelen-Schipper 2018, p. 297. Zie ook MvT BTRP, p. 35. 
nen maken van artikel 2:298 BW. ${ }^{40} \mathrm{~A}-\mathrm{G}$ Timmerman schrijft in zijn conclusie bij dit arrest dat de rechter bij de uitleg van het begrip 'belanghebbende' een middenweg dient te vinden tussen een te ruime uitleg, waarmee artikel 2:298 BW een actio popularis wordt, en een te enge uitleg, waarmee artikel 2:298 BW een papieren tijger wordt. Niet iedereen die zich betrokken voelt bij het doel of de activiteiten van de stichting moet ontvankelijk zijn; er moet sprake zijn van een redelijk belang.

In sectorcodes wordt soms opgesomd wie als belanghebbenden bij stichtingen in de desbetreffende sector worden aangemerkt. Naast de hiervoor genoemde belanghebbenden worden bijvoorbeeld vrijwilligers en gemeenten genoemd. Als een vrijwilliger van een zorginstelling een verzoek tot ontslag van een bestuurder (of straks lid van de raad van toezicht) op grond van artikel 2:298 BW wil indienen, is mogelijk relevant dat vrijwilligers in een sectorcode uitdrukkelijk als belanghebbenden worden genoemd. Opstellers van codes dienen zich daarvan bewust te zijn.

\subsection{Enquêterechtelijke trekken van artikel 2:298 BW}

In de literatuur is al een tijdje geleden opgemerkt dat in de rechtspraak een trend waarneembaar is die erop neerkomt dat de artikel 2:298 BW-procedure enquêterechtelijke trekken krijgt. ${ }^{41}$ Wat ten eerste opvalt, is dat in de rechtspraak over artikel 2:298 BW soms de term 'wanbeleid' in plaats van 'wanbeheer' wordt gehanteerd. ${ }^{42}$ Bovendien kan de rechtbank op grond van artikel 2:298 lid 2 BW hangende het onderzoek voorlopige voorzieningen treffen en de bestuurder schorsen. ${ }^{43}$ Een voorlopige voorziening kan bijvoorbeeld inhouden: het benoemen van een tijdelijke bestuurder, die de opdracht krijgt om onderzoek te verrichten naar de gang van zaken binnen de stichting en daarvan verslag uit te brengen aan de rechtbank. ${ }^{44}$

\subsection{Mogelijkheden van het enquêterecht en kring van enquêtegerechtigden}

Het doel van de enquête is natuurlijk wel ruimer dan dat van artikel 2:298 BW. ${ }^{45}$ Het enquêterecht maakt het mogelijk om

40. HR 12 oktober 2018, NJ 2018/412, JOR 2018/296, RO 2018/77 (Stichting ANV Fondsen). In dit geval wilde de oud-bestuurder van een gelieerde vereniging van Stichting ANV Fondsen als belanghebbende van deze stichting worden aangemerkt teneinde het bestuursbeleid inzake de vergoedingen van de stichting aan de gelieerde vereniging aan de orde te stellen.

41. Asser/Rensen 2-III 2017/352 en Blanco Fernández in zijn noot bij JOR 2015/195.

42. Zie Hof Amsterdam 21 juli 2015, RO 2015/64 (Castle Capital).

43. Vgl. art. 2:349a lid $2 \mathrm{BW}$ bij de enquêteprocedure.

44. Zie bijv. Rb. Noord-Holland 30 juni 2016, ECLI:NL:RBNHO: 2016:5331 (Stichting Loterijverlies), Rb. Rotterdam 6 maart 2013, JOR 2013/100 en Rb. Rotterdam 24 juli 2013, JOR 2013/271 (Stichting Mayflower), waarover Asser/Rensen 2-III 2017/352. Vgl. art. 2:345 e.v. BW bij de enquêteprocedure.

45. Van der Ploeg meent dat er veel voor te zeggen is om art. 2:298 BW om te bouwen tot een 'mini-enquêteprocedure', waarbij belanghebbenden de rechtbank ook kunnen verzoeken om besluiten van stichtingsorganen te schorsen of te vernietigen. T.J. van der Ploeg, Overheidstoezicht op stichtingen, in: M.L. Lennarts, W.J.M. van Veen \& D.F.M.M. Zaman (red.), De stichting. Kritische beschouwingen over de wettelijke regeling voor een veelzijdige rechtspersoon. Den Haag: Sdu Uitgevers 2011. bij de Ondernemingskamer (OK) gedragingen van het bestuur en de raad van toezicht te laten onderzoeken en oplossingen te vinden voor patstellingen. Het enquêterecht van artikel 2:345 e.v. BW is slechts van toepassing op een stichting met een grote onderneming waarin ten minste vijftig werknemers werkzaam zijn (art. 2:344 BW). Indien de OK vaststelt dat sprake is van wanbeleid bij een dergelijke stichting, kan zij bestuurders en leden van de raad van toezicht bij wege van een definitieve voorziening ontslaan (art. 2:356 BW). De kring van mogelijke verzoekers van een enquête bij een stichting is echter klein. Een verzoek tot het instellen van een onderzoek naar het beleid en de gang van zaken binnen de stichting kan worden ingediend door de stichting zelf, vertegenwoordigd door haar bestuur of raad van toezicht, een vakbond, ${ }^{46}$ de A-G bij het Gerechtshof Amsterdam (om redenen van openbaar belang) of degene die deze bevoegdheid heeft op grond van de statuten of een overeenkomst met de stichting (art. 2:344-347 $\mathrm{BW})$.

Sectorregels breiden bij bepaalde soorten stichtingen de wettelijke kring van enquêtegerechtigden uit. Stichtingen die een zorginstelling exploiteren waarvoor een ondernemingsraad moet worden ingesteld, dienen in hun statuten het enquêterecht toe te kennen aan de cliëntenraad. ${ }^{47}$ In het Wetsvoorstel medezeggenschap cliënten zorginstellingen, dat op dit moment bij de Eerste Kamer ligt, is voorgesteld om dit recht rechtstreeks (bij wet, dus niet via de statuten) toe te kennen aan de cliëntenraad. ${ }^{48}$ In de parlementaire geschiedenis bij het Wetsvoorstel medezeggenschap cliënten zorginstellingen is te lezen dat in de praktijk in de statuten van zorginstellingen drempels worden opgeworpen waardoor het voor de cliëntenraad feitelijk niet mogelijk is om een enquêteverzoek in te dienen. ${ }^{49}$ Overigens wordt ook opgemerkt dat enquêteverzoeken zelden worden ingediend door de cliëntenraad. Sinds de inwerkingtreding van de WTZi zijn er vijf zaken geweest. ${ }^{50}$ Daarnaast bepaalt de Pensioenwet voor pensioenfondsen dat het verantwoordingsorgaan, het zogenoemde belanghebbendenorgaan en de raad van toezicht het recht hebben om een enquêteverzoek in te dienen. ${ }^{51}$

Voor woningstichtingen is een bijzondere bepaling opgenomen in de Woningwet, die inhoudt dat de OK exclusief bevoegd is om een lid van de raad van toezicht (daar commissaris genoemd) van de woningstichting te ontslaan (art. 33 lid 1 Woningwet). Het verzoek daartoe kan worden ingediend door de woningstichting zelf of door de minister van Binnen-

46. Een bekend voorbeeld van een enquête bij een zorginstelling die op verzoek van de vakbond werd ingesteld, is de enquête bij Meavita (Hof Amsterdam (OK) 2 november 2015, JOR 2016/61, RO 2016/8).

47. Zie art. 6.2 Uitvoeringsbesluit WTZi.

48. Art. 12 Wetsvoorstel medezeggenschap cliënten zorginstellingen, Kamerstukken I 2018/19, 34858, A.

49. Kamerstukken I 2017/18, 34858, 3, p. 23.

50. Zie bijv. Hof Amsterdam (OK) 29 april 2010, JOR 2010/187 (Stichting Zorgcentra de Betuwe) en Hof Amsterdam (OK) 20 mei 2010, JOR 2010/188 (Stichting Sherpa). Kamerstukken I 2017/18, 34858, 3, p. 23.

51. Art. 219 Pensioenwet. 


\section{Maandblad \\ Ondernemingsrecht}

landse Zaken en Koninkrijksrelaties (BZK). De bepaling in de Woningwet vervolgt dat de OK uitsluitend overgaat tot ontslag als sprake is van verwaarlozing van de toezichthoudende taak, wegens andere gewichtige redenen of wegens ingrijpende wijziging van de omstandigheden op grond waarvan het aanblijven als lid van de raad van toezicht redelijkerwijs niet van de woningstichting kan worden verlangd. ${ }^{52}$ Deze gronden uit de Woningwet komen overeen met de nieuwe gronden van artikel 2:298 BW in het Wetsvoorstel BTRP.

\subsection{Verhouding tussen artikel 2:298 BW en het enquêterecht}

Meerdere auteurs hebben zich afgevraagd wat de verhouding is tussen de artikel 2:298 BW-procedure en de enquêteprocedure. ${ }^{53} \mathrm{Via}$ beide procedures kan schorsing of ontslag van een bestuurder worden bewerkstelligd, kan een tijdelijk bestuurder worden benoemd en kan onderzoek worden verricht naar de gang van zaken binnen de stichting. Op zichzelf lijkt het niet bezwaarlijk dat beide procedures naast elkaar bestaan. ${ }^{54}$ Niettemin kan de vraag worden gesteld of sectorregels die aan belanghebbenden(organen) het enquêterecht toekennen nog wel nodig zijn als de mogelijkheden van artikel 2:298 BW met de invoering van het Wetvoorstel BTRP zijn verruimd. Ik ben het met Klaassen eens dat voorzichtig omgegaan moet worden met de uitbreiding van enquêtegerechtigden in sectorale wetgeving. Van belang is dat steeds zorgvuldig wordt afgewogen of de belanghebbenden(organen) toegang dienen te krijgen tot de enquêteprocedure, aangezien dergelijke procedures ingrijpend zijn voor de stichting in kwestie. ${ }^{55}$ Klaassen merkt daarbij, evenals Overes, terecht op dat in ieder geval kan worden getwijfeld aan de noodzaak om de minister van BZK de bevoegdheid te geven om via de OK leden van de raad van toezicht van een woningstichting te ontslaan. ${ }^{56}$ Deze bepaling dient mijns inziens, mede in verband met de invoering van het nieuwe artikel 2:298 Wetsvoorstel BTRP, te worden

52. Art. 33 Woningwet.

53. Zie o.m. H.E. Boschma, M.L. Lennarts, J.N. Schutte-Veenstra \& J.B. Wezeman, Naar een betere regeling van bestuur en toezicht bij verenigingen en stichtingen in de semipublieke sector, RMThemis 2014, afl. 4, p. 159-171, C.H.C. Overes, Worstelen met governance van semipublieke instellingen en pensioenfondsen, WPNR 2013/6996, L.G.H.J. Houwen, Herzieningswet bestuur en toezicht: effecten voor het semipublieke domein, TvOB 2014, afl. 4, p. 135-147, M. Koelemeijer, De nieuwe ontslagregeling voor de stichting, naar een beter bestuur en toezicht?, TvOB 2016, afl. 1, p. 27, H. Koster, Overpeinzingen over wanbeheer, onderzoek en voorlopige voorzieningen bij stichtingen (art. 2:298 BW), TvOB 2014, afl. 6, p. 192-197 en A.G.H. Klaassen, Het wetsvoorstel Wet bestuur en toezicht rechtspersonen en de semipublieke sector: een betere aansluiting op Boek $2 \mathrm{BW}$ is wenselijk, Ondernemingsrecht 2017/107.

54. In gelijke zin Klaassen 2017. Koster meent echter dat de regeling van art. 2:298 BW (in ieder geval voor zover het lid 2 van art. 2:298 BW betreft) beter in het enquêterecht, dus bij de OK, kan worden ondergebracht (Koster 2014). De OK heeft immers veel ervaring met dit soort kwesties en de enquêteprocedure is meer uitgewerkt en uitgekristalliseerd, aldus Koster.

55. Klaassen 2017.

56. Klaassen 2017; Overes 2013. Houwen twijfelt bovendien aan het toekennen van enquêterecht aan cliëntenraden, aangezien deze mogelijk onvoldoende distantie hebben tot de zorginstelling (L.G.H.J. Houwen, Toezicht op zorgondernemingen, NJB 2005, p. 1232-1233). geschrapt. Cliëntenraden van een zorginstelling maken, als gezegd, af en toe gebruik van het enquêterecht, maar - voor zover mij bekend - nog niet van artikel 2:298 BW. ${ }^{57}$ Het valt te bezien of cliëntenraden en andere belanghebbenden(organen) wel gebruik gaan maken van artikel 2:298 BW als met de invoering van het Wetsvoorstel BTRP de ontslaggronden worden uitgebreid en ook leden van de raad van toezicht onder het artikel vallen. In sommige gevallen, bijvoorbeeld wanneer 'slechts' beoogd wordt leden van de raad van toezicht te schorsen of te ontslaan, kan het enquêterecht mijns inziens een (te) zwaar middel zijn en biedt artikel 2:298 BW een beter alternatief.

\section{Conclusies}

Als het Wetsvoorstel BTRP in de huidige vorm wet wordt, biedt het een stevige basis voor de uitwerking van verschillende governancemodellen bij stichtingen in diverse sectoren. Voor het model met een 'gewoon bestuur', het model met verschillende soorten bestuurders (de one-tier board) en voor het raad-van-toezichtmodel worden belangrijke bouwstenen geleverd. Stichtingen die een $\mathrm{AB} / \mathrm{DB}$-model hanteren, zouden na moeten gaan of dit model feitelijk kwalificeert als een raadvan-toezichtmodel, een one-tier board of een bestuur/directiemodel. Bij het bestuur/directiemodel is het statutair bestuur (bestuur in de zin van de wet) eindverantwoordelijk voor de (titulaire) directeuren.

Naast het raad-van-toezichtmodel zou ook het model met een one-tier board het uitgangspunt kunnen zijn van sectorwetten en governancecodes. Sectorregels en governancecodes dienen zich primair te richten tot het bestuur en de raad van toezicht in de zin van de (toekomstige) wet en in beginsel niet tot de titulaire directie. Niettemin zijn diverse bepalingen van good governance, zoals integriteitsbepalingen, ook relevant voor titulair directeuren, die handelen onder verantwoordelijkheid van het statutair bestuur. In sectoren waar het bestuur/directiemodel vaak voorkomt, kunnen brancheorganisaties dit uitwerken in handreikingen of voorbeeldbepalingen voor een directiereglement.

Het Wetsvoorstel BTRP bevat minimale kernbevoegdheden voor het bestuur en de raad van toezicht, die in sectorwetten en sectorcodes uitgewerkt dienen te worden. Het is van belang om de toezichthoudende taak van de raad van toezicht en de niet-uitvoerende bestuurders verder in te kleuren, bijvoorbeeld door toekenning van goedkeuringsbevoegdheid ten aan-

57. Wellicht komt dat omdat cliëntenraden via een enquête het beleid en de gang van zaken bij een zorginstelling in volle omvang willen laten toetsen. Bovendien hoeft de cliëntenraad in dat geval minder te stellen en te bewijzen, omdat voldoende is dat sprake is van gegronde redenen om aan een juist beleid te twijfelen. Het zou ook kunnen dat zij de OK het meest competent achten vanwege het specifieke karakter van een zorginstelling die met een veelheid aan belangen en complexe regels te maken heeft. Overigens is in het verleden ook wel gesuggereerd om binnen de OK raden te benoemen met kennis van de zorgsector. Zie H.K. Gussinklo, Wanbeleid in de zorg. Het toetsingskader in een enquêteprocedure bij een zorginstelling, Ondernemingsrecht 2009/95. 


\section{Maandblad}

zien van nader te bepalen belangrijke bestuursbesluiten. Aangezien het Wetsvoorstel BTRP niet voorschrijft dat de statuten van een stichting een regeling van belet en ontstentenis van alle bestuurders of leden van de raad van toezicht bevatten, dient dit voorschrift opgenomen te worden in sectorregels en sectorcodes. Bovendien is van belang dat in sectorcodes aanvullingen op de wettelijke tegenstrijdig-belangregeling opgenomen worden. Nadere handreikingen over zorgvuldige besluitvorming door het bestuur en de raad van toezicht kunnen bijdragen aan daadwerkelijk goede governance.

Het voorgestelde artikel 2:298 BW geeft belanghebbenden van de stichting ruimere mogelijkheden om bestuurders en leden van de raad van toezicht die het belang van de stichting schaden, te ontslaan. De rechtbank kan, hangende het onderzoek, voorlopige voorzieningen treffen en de bestuurder of het lid van de raad van toezicht schorsen. De artikel 2:298 BWprocedure, die enquêterechtelijke trekken vertoont, zou een instrument kunnen worden dat vaker dan nu wordt ingezet. Aan sommige belanghebbenden(organen), zoals cliëntenraden bij zorginstellingen, is op dit moment in sectorregels enquêterecht toegekend. Het nieuwe artikel 2:298 BW biedt dergelijke belanghebbenden een minder zwaar en wellicht beter alternatief om leden van de raad van toezicht die hun taak verwaarlozen via de rechter te schorsen of te ontslaan. 